\title{
Akuntabilitas Pelayanan Publik Dalam Pembuatan Surat Izin Mengemudi di Polres Kediri Tahun 2019-2020
}

\author{
Intan Regina Maghfirani' ${ }^{1}$, Muhammad Khozin ${ }^{2}$ \\ ${ }^{1,2}$ Universitas 'Aisyiyah Yogyakarta, Indonesia \\ Email Korespondensi: reginaintan26@gmail.com
}

\begin{abstract}
Abstrak: Tujuan penelitian ini adalah untuk mengetahui akuntabilitas pelayanan publik dalam pembuatan SIM dan faktor-faktor yang mempengaruhi pelayanan publik di Polres Kediri. Penelitian ini menggunakan metode penelitian kualitatif. Berdasarkan hasil penelitian yang dilakukan dapat disimpulkan bahwa akuntabilitas pelayanan publik di Polres Kediri sudah dapat dikatakan baik dan sesuai dengan Standar Operasional Prosedur (SOP). Selain itu, terdapat faktor-faktor yang mendukung dan menghambat proses pelayanan publik di Polres Kediri.
\end{abstract}

Kata kunci; Akuntabilitas; Pelayanan; Publik.

Abstract: The purpose of this study was to determine the accountability of public services in making SIM and the factors that affect public services at the Kediri Police. This study used qualitative research methods. Based on the results of the research conducted, it can be concluded that the accountability of public services at the Kediri Police Station can be said to be good and in accordance with Standard Operating Procedures (SOP). In addition, there are factors that support and hinder the public service process at the Kediri Police.

Keywords: Accountability; Service; Public.

Article History:

Received: 5-8-2020; Revised: 25-9-2020; Accepted: 10-11-2020

\section{PENDAHULUAN}

Dalam menghadapi era globalisasi yang penuh tantangan dan peluang, Aparatur Sipil Negara (ASN) dalam hal ini aparatur kepolisian sebagai pelayan masyarakat dihadapkan pada tugas pokok yang cukup berat. Reformasi diharapkan memberikan dampak positif terhadap sistem dalam penyelenggaraan pemerintahan. Hal ini tentunya dapat dilihat dari keberpihakan yang dilakukan pemerintah terhadap kepentingan masyarakat. Namun realitanya, Korupsi, Kolusi dan Nepotisme $(\mathrm{KKN})$ semakin meluas di Indonesia yang hal tersebut tentunya memberi dampak yang negatif terhadap sistem dan citra pelayanan publik di hadapan masyarakat. Di samping itu, kasus Korupsi, Kolusi dan Nepotisme (KKN) di berbagai daerah juga marak terjadi (Lavenia, 2018). Salah satu contoh kasus Korupsi, Kolusi dan Nepotisme (KKN) adalah kasus pungli Surat Izin Mengemudi (SIM).

Dalam Peraturan Pemerintah RI Nomor 50 Tahun 2010 tentang Jenis dan Tarif atas Jenis Penerimaan Negara Bukan Pajak sudah dijelaskan mengenai biaya dalam proses penerbitan SIM. Penerbitan SIM A dan B dikenakan biaya sebesar Rp.120.000,- (seratus dua puluh ribu rupiah). Untuk penerbitan SIM C dikenakan biaya sebesar Rp.100.000,- (seratus ribu rupiah). Namun pada praktiknya, hal tersebut tidak berjalan sebagaimana mestinya. Dari pantauan tim Saber Pungli Polri menemukan bahwa setiap Permohonan SIM dikenakan biaya diluar ketentuan Penerimaan Negara Bukan Pajak (PNBP) yakni sebesar Rp. 500.000,- (lima ratus ribu rupiah) sampai Rp 600.000 (enam ratus ribu rupiah) perorang (Samudra, 2019). Hal ini membuktikan bahwa adanya peran calo didalam proses pembuatan SIM.

Dengan kondisi tersebut, banyak masyarakat yang merasa kurang nyaman, karena aktivitas calo yang membuat resah dan seolah malah mendapatkan restu dari pihak kepolisian (Media, 2018). 
Dengan adanya masalah tersebut, pemerintah diharuskan melakukan evaluasi dalam setiap pelayanan yang diberikan dan melakukan pembenahan yang berkaitan dengan kualitas pelayanan yang diberikan kepada masyarakat. Proses pemberian layanan kepada masyarakat harus dilakukan secara efektif, profesional, adil, ramah, demokratis, dan impersonalitas.

Peran kepolisian sebagai pelayan masyarakat khususnya pada unit pelayanan SIM sangat diperlukan. Agar masyarakat dapat percaya bahwa dalam proses pembuatan SIM tidaklah rumit seperti apa yang mereka fikirkan selama ini. Dimana mereka masih sering beranggapan bahwa untuk mendapatkan SIM harus melewati sebuah proses yang sangatlah rumit dan bertele-tele, bahkan sebagian masyarakat masih tertarik dengan menggunakan cara instan dengan rela mengeluarkan uang yang cukup besar kepada para calo.

Meski biaya menjadi naik berkali lipat, namun masih banyak masyarakat yang menggunakan jasa calo tersebut. Hal ini karena mereka akan dapat dengan cepat memperoleh Surat Izin Mengemudi (SIM). Berkaca dari permasalahan tersebut, banyak hal yang harus dibenahi dalam penyelenggaraan pelayanan kepada masyarakat. Salah mengenai isu akuntabilitas petugas pelayanan kepada masyarakat. Akuntabilitas adalah sebuah keadaan yang dapat dipertanggung jawabkan. Menurut kumorotomo (2005), akuntabilitas adalah sebuah tolak ukur mengenai sistem birokrasi publik yang dilakukan pemerintah (Munawaroh et al., 2020). Hal ini karena untuk mengetahui apakah sistem tersebut sejalan dengan norma yang berlaku di masyarakat. Selain itu, juga untuk mengetahui apakah pelayanan yang diberikan kepada masyarakat sudah berhasil dalam pemenuhan kebutuhan masyarakat itu sendiri.

Akuntabilitas diperlukan pada setiap aparatur pemerintah, sehingga mempunyai tanggung jawab dari semua tindakan dan pekerjaannya kepada public (Faidati \& Khozin, 2020). Akuntabiltas publik juga terkait dengan kewajiban untuk menjelaskan dan menjawab pertanyaan mengenai dengan apa yang telah, sedang dan direncanakan akan dilakukan oleh organisasi sektor public (Lestari et al., 2018).

Akuntabilitas harus diketahui dan dipahami oleh setiap instansi pemerintahan di Indonesia, baik pemerintahan daerah maupun pusat. Hal ini karena akuntabilitas sangat penting sebagai salah satu bentuk laporan dalam proses terbitnya SIM. Sebagai contoh, standart penerbitan SIM baru secara umum memerlukan waktu 120 menit, akan tetapi dalam kenyataannya bisa memerlukan waktu sekitar tiga hari. Berkaitan dengan hal ini, akuntabilitas harus diterapkan agar dapat digunakan untuk memperbaiki kinerja pegawai, sehingga dapat menyelesaikan pembuatan Surat Izin Mengemudi (SIM) dengan tepat waktu.

Salah satu kasus pungli SIM terjadi di Kediri. Hal ini dapat dilihat dari adanya kasus Operasi Tangkap Tangan (OTT) yang dilakukan oleh Tim Saber Pungli Mabes Polri pada tahun 2018 yang menjerat Kapolres Kediri dan lima pegawai sipil yang terlibat di dalamnya. Selain itu, masih dijumpai berbagai keluhan masyarakat terhadap pelayanan yang diselenggarakan di Polres Kediri (Media, 2018).

Adapun keluhan-keluhan yang sering terdengar dari masyarakat adalah waktu dalam pelayanan penerbitan Surat Izin Mengemudi (SIM) dan terjadinya transaksi di luar administrasi dalam penerbitan Surat Izin Mengemudi (SIM). Hal ini karena bagi yang menggunakan perantara akan lebih dipermudah dalam mendapatkan SIM. Selain itu, di kantor Polres Kediri masih terdapat beberapa calo yang berkeliaran. Meski hal ini sudah dilarang melalui pengumuman yang ditempel pada beberapa dinding, namun praktik ini tetap saja terjadi.

Berdasarkan paparan data di atas, maka dapat disimpulkan bahwa permasalahan yang terjadi di Polres Kediri adalah menyangkut akuntabilitas atau pertanggung jawaban Petugas pelayanan publik dalam melakukan atau memberikan suatu pelayanan kepada masyarakat. Berdasarkan masalahmasalah yang dipaparkan sebelumnya, penulis tertarik untuk melakukan penelitian dengan judul "Akuntabilitas Pelayanan publik dalam Pembuatan Surat Izin Mengemudi (SIM) di Polres Kediri Pada Tahun 2019-2020".

Berdasarkan permasalahan yang telah dirumuskan dalam sebuah perumusan masalah, maka dapat ditentukan tujuan penelitian, yaitu untuk mengetahui tingkat akuntabilitas pelayanan dalam penerbitan Surat Izin Mengemudi (SIM) di Kantor Polres Kediri. Selain itu, untuk mengetahui apa saja faktor-faktor yang menghambat akuntabilitas dalam pelayanan penerbitan Surat Izin Mengemudi (SIM) di Kantor Polres Kediri. 


\section{METODE PENELITIAN}

Metode penelitian yang digunakan pada studi ini adalah metode kualitatif. Metode kualitatif sebagai prosedur penelitian yang menghasilkan data deskriptif berupa kata-kata tertulis atau lisan dari orang-orang atau pelaku yang diamati (Moleong, 2014). Metode kualitatif ini digunakan karena beberapa pertimbangan yaitu metode kualitatif lebih bisa dan mudah menyesuaikan apabila berhadapan dengan kenyataan ganda, metode ini menyajikan hakekat yang berhubungan antara peneliti dan responden secara langsung dan metode ini lebih peka sehingga dapat menyesuaikan diri dan banyak penajaman pengaruh bersama terhadap pola-pola nilai yang dihadapi peneliti.

Penelitian ini dilaksanakan di Kantor Polres Kediri yang berada dijalan raya kediri-pare, Kabupaten Kediri, Jawa Timur. Alasan penulis mengambil lokasi ini karena telah terjadi OTT (Operasi Tangkap Tangan) yang dilakukan oleh tim siber pungli dan masih terjadi permainan dibelakang seperti halnya dengan menggunakan jasa calo dan masih banyak terjadi pemesananpemesanan yang terjadi. Penelitian ini menggunakan teknik pengumpulan data berupa observasi, wawancara, dan doumentasi. Observasi dapat dilakukan dengan dua cara yaitu observasi partisipasi dan non-partisipasi. Observasi partisipasi dapat digunakan apabila peneliti ikut terlibat secara langsung. Sedangkan observasi non-partisipasi adalah observasi yang dilakukan dimana peneliti tidak menyatu degan yang diteliti, sehingga hanya sekedar mengamati. Wawancara dapat dikatakan sebagai proses atau kegiatan yang menjadi penentu keberhasilan sebuah penelitian. Dokumentasi dalam penelitian dapat berbentuk buku harian, laporan berkala, jadwal kegiatan, anggara dasar dan surat resmi dan lain sebagainya.

Teknik analisis data yang digunakan adalah kualitatif yaitu salah satu analisis terhadap data tidak dinyatakan dalam bentuk angka tetapi dalam bentuk uraian-uraian yang disusun secara sistematis dari apa yang dinyatakan oleh narasumber atau responden secara lisan maupun tertulis dan juga perilakunya yang nyata diteliti dan dipelajari sebagai bagian yang utuh. Tahapan-tahapan yang di lalui dalam menganalisis data ini adalah editing, coding, dan interpretasi

\section{HASIL DAN PEMBAHASAN}

Pada bagian ini akan diuraikan tentang (1) akuntabilitas kinerja pelayanan publik, (2) akuntabilitas biaya pelayanan publik, (3) akuntabilitas produk pelayanan publik, dan (4) faktor-faktor yang mempengaruhi pelayanan publik.

\section{Akuntabilitas Kinerja Pelayanan Publik}

Akuntabilitas kinerja dalam pelayanan publik adalah salah satu hal yang sangat menentukan keberhasilan sebuah pelayanan publik. Berdasarkan keputusan Menteri Pedayagunaan Aparatur Negara (MENPAN) No 24 Tahun 2006, dijelaskan bahwa cakupan dalam akuntabilitas kinerja pelayanan publik antara lain adalah (1) Petugas yang profesional, sarana dan prasarana yang lengkap, dan jelasnya kebijakan yang berlaku; (2) Kesesuaian kinerja pelayanan publik dengan standar yang telah ditetapkan; (3) Keterbukaan standar pelayanan; (4) Penyimpangan-penyimpangan yang mungkin terjadi; (5) Diberikannya kesempatan kepada masyarakat untuk melakukan penelitian yang ada kaitannya dengan kinerja pelayanan publik; (6) Adanya tanggungjawab bilamana ada kerugian.

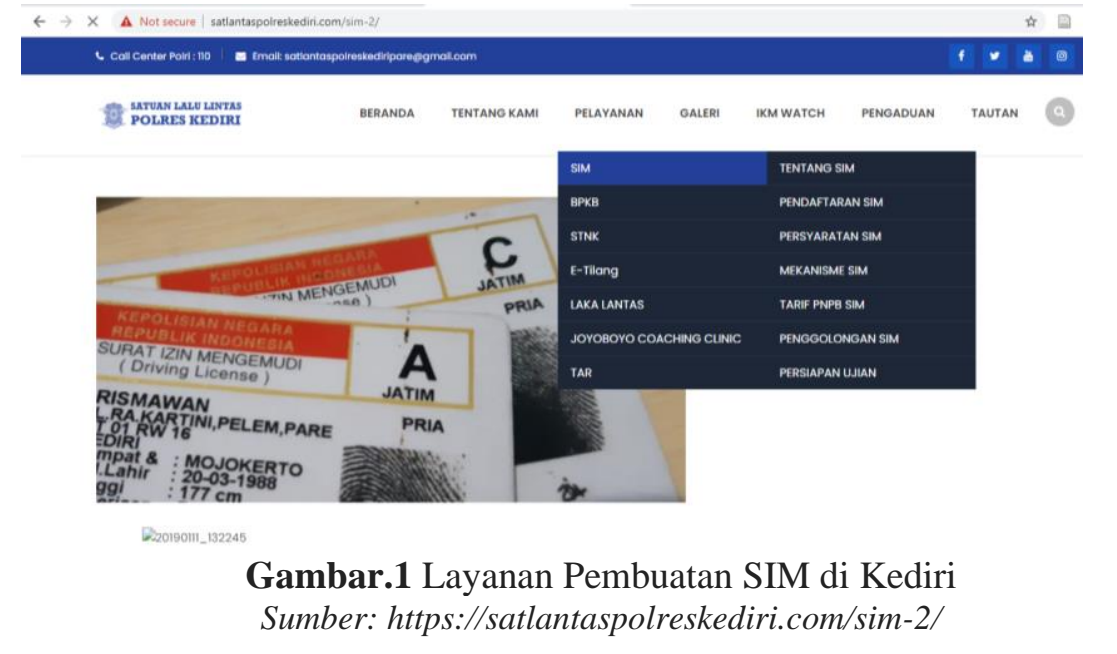


Dilihat dari gambar.1 layanan pembuatan SIM di Kediri sudah lebih mudah dan baik. Namun, beberapa kondisi terkait kinerja pelayanan publik yang terjadi di lapangan, tepatnya di Polres Kediri berhasil peneliti kupas dalam penelitian ini. Adapun untuk mengetahui akuntabilitas kinerja pelayanan publik peneliti melakukan penggalian informasi terkait mekanisme dan profesionalisme petugas dalam memberikan pelayanan, sarana dan prasarana, kemungkinan terjadinya penyimpanganpenyimpangan atas prosedur yang telah dimiliki oleh Polres Kediri dan juga terkait keberadaan calo. Adapun detil dari masing-masing unsur akan peneliti paparkan berikut ini.

Pertama, Mekanisme dan profesionalitas dalam melakukan pelayanan publik. Proses kinerja pelayanan publik yang dilakukan di Polres Kediri sudah dapat dikatakan baik, bertanggungjawab, dan sesuai dengan Standart Operasional Prosedural (SOP) yang berlaku. Hal ini juga sesuai dengan keputusan Menteri Pedayagunaan Aparatur Negara (MENPAN) No.24 Tahun 2006 tentang Petunjuk Teknis Transparansi dan Akuntabilitas dalam penyelenggaraan Pelayanan Publik dapat dikatakan bahwa penyelenggaraan publik harus dapat dipertanggungjawabkan, baik pada publik maupun kepada pimpinan unit pelayanan yang sesuai dengan ketentuan peraturan perundang-undangan.

Kedua, sarana dan prasarana. Sarana dan prasarana merupakan salah satu aspek yang sangat mendukung proses kinerja pelayanan publik agar dapat melayani masyarakat dengan maksimal. Tanpa sarana dan prasarana yang memadai, maka proses pelayanan juga tidak akan berjalan sesuai dengan ketentuan yang berlaku. Sarana dan prasarana yang ada di Polres Kediri sudah baik dan memadai untuk mendukung proses kinerja pelayanan publik secara baik dan bertanggungjawab. Hal ini dapat memberikan dampak yang positif khususnya kepada masyarakat selaku pemohon pelayanan SIM yang akan merasa nyaman dan merasakan kemudahan dalam proses pelayanan.

Ketiga, penyimpangan. Tidak dapat dipungkiri bahwa penyimpangan-penyimpangan sering kali terjadi dalam setiap proses kegiatan pelayanan dalam bidang apapun, termasuk dalam bidang kinerja pelayanan publik. Penyimpangan ini bisa berbagai macam, mulai dari penyimpangan yang dilakukan pihak internal maupun eksternal. Berdasarkan penelitian yang dilakukan, diperoleh hasil bahwa tidak ada penyimpangan-penyimpangan yang terjadi dan dilakukan oleh petugas pelayanan di Polres Kediri. Hal ini dibuktikan dengan tidak adanya keluhan dari masyarakat terkait hal tersebut. Selain itu, Polres Kediri rutin melakukan evaluasi kerja setiap satu bulan sekali yang dapat mendukung meminimalisir penyimpangan yang dilakukan oleh petugas pelayanan. Sepertinya yang ditulis oleh (Permatasari, 2020) yang memaparkan bahwa evaluasi juga menjadi tolak ukur terhadap kebijakankebijakan selanjutnya yang akan diambil pemerintah atau pelaksana. Buku ini ditulis dengan sangat baik, runut dan mudah dipahami.

\section{Akuntabilitas Biaya Pelayanan Publik}

Akuntabilitas biaya pelayanan publik adalah besaran dan rincian biaya pelayanan yang wajib dikeluarkan, dalam hal ini adalah pelayanan pembuatan SIM. Cakupan dalam akuntabilitas biaya pelayanan publik antara lain adalah (1) Biaya pelayanan dipungut sesuai dengan ketentuan dalam peraturan perundang-undangan yang berlaku; (2) Pengaduan masyarakat yang terkait dengan penyimpangan biaya pelayanan publik harus ditangani oleh petugas yang ditunjuk berdasarkan Surat Keputusan atau Penugasan dari pejabat yang berwenang. Beberapa kondisi yang terjadi berkaitan dengan akuntabilitas biaya pelayanan publik di Polres Kediri sebagaimana disebutkan berikut.

Pertama, kesesuaian biaya pelayanan. Permasalahan menganai biaya memang dapat dikatakan sebagai masalah yang krusial dan memang sangat penting. Permasalahan menganai biaya acap kali membuat adanya masalah-masalah atau keresahan khususnya pada masyarakat. Berdasarkan penelitian yang telah dilakukan, diperoleh hasil bahwa kesesuaian biaya dalam pelayanan publik yang berlaku di Polres Kediri sudah sesuai dengan Standart Operasional Prosedur (SOP) yang telah ditetapkan dalam perundang-undangan. Artinya, masalah biaya dalam pelayanan khususnya SIM tidak dapat dimanipulasi oleh siapapun. Hal ini juga didukung dengan informasi dari sejumlah warga yang melakukan proses pelayanan SIM. Tiga orang yang peneliti jumpai di lapangan dalam hari yang sama semua mengatakan tidak ada pungutan liar lagi diluar ketentuan. Biaya yang dikeluarkan sudah sesuai dengan ketentuan yang berlaku dan dipasang pada area pelayanan.

Kedua, berkaitan dengan keluhan atau aduan masyarakat mengenai biaya pelayanan. Seperti yang telah dipaparkan pada pembahasan sebelumnya bahwa masalah yang terkait dengan biaya adalah masalah yang sangat sensitif. Berkenaan dengan hal itu, maka memungkinkan adanya aduan-aduan atau keluhan yang dilakukan oleh masyarakat selaku pemohon kepada petugas pelayanan. 
Berdasarkan penelitian yang telah dilakukan, diperoleh hasil bahwa tidak ada keluhan masyarakat mengenai biaya pelayanan SIM. Hal ini karena biaya untuk pelayanan SIM sudah ditetapkan dan sesuai dengan SOP yang berlaku. Artinya, biaya sudah paten dan tidak dapat diganggu gugat.

Ketiga, berkaitan dengan adanya calo. Tidak dapat dipungkiri bahwa keberadaan calo sangat meresahkan. Selain itu, sejatinya keberadaan calo adalah hal yang tidak benar. Berkaitan dengan itu, instansi yang memberikan jasa pelayanan harus bisa mengambil langkah untuk meminimalisir bahkan menghilangkan kegiatan calo. Berdasarkan penelitian yang telah dilakukan, diperoleh hasil bahwa dengan adanya calo dapat meresahkan masyarakat, sehingga beberapa langkah diambil oleh petugas untuk dapat meminimalisir adanya calo, Antara lain adalah dengan memberikan himbauan dan pemahaman kepada masyarakat melalui banner atau poster. Selain itu, juga memberlakukan sistem online untuk pengurusan SIM.

\section{Akuntabilitas Produk Pelayanan Publik}

Produk pelayanan adalah hasil dari proses pelayanan, dalam hal ini adalah Surat Izin Mengemudi (SIM). Cakupan dalam produk pelayanan Publik adalah (1) Persyaratan teknis dan administratif harus jelas dan dapat dipertanggungjawabkan dari berbagai segi, baik dari segi kualitas maupun dari segi keabsahan produk pelayanan; (2) Prosedur dan mekanisme kerja harus sederhana dan dilaksanakan sesuai dengan ketentuan yang telah ditetapkan; (3) Produk pelayanan diterima dengan benar, tepat waktu dan sah. Beberapa kondisi yang terjadi di Polres Kediri mengenai produk pelayanan publik adalah sebagai berikut.

Pertama, terkait dengan persyaratan teknis dan administratif dan keabsahan produk, serta pengambilan produk pelayanan. Sebagian besar masyarakat lebih mementingkan kecepatan penerbitan SIM daripada proses mendapatkannya yang sesuai dengan prosedur. Berdasarkan penelitian yang telah dilakukan, diperoleh hasil bahwa masalah persyaratan teknis dan administratif, keabsahan produk, serta pengambilan produk pelayanan di Polres Kediri dapat dipertanggungjawabkan. Hal ini karena di Polres Kediri, proses pembuatan SIM dari awal sampai jadi hanya memakan waktu satu hari saja. Artinya, tidak ada alasan bahwa pembuatan SIM memerlukan waktu yang cukup lama.

Kedua, berkaitan prosedur kerja dan standart pelayanan publik. Prosedur dan standart kerja yang dilakukan oleh petugas pelayanan haruslah sesuai dengan standart yang telah ditetapkan. Hal ini bertujuan untuk meminimalisir adanya hal-hal yang tidak sesuai dengan standart pelayanan. Selain itu, agar bisa melayani masyarakat secara maksimal. Berdasarkan penelitian yang telah dilakukan, diperoleh hasil bahwa prosedur kerja dan standart pelayanan publik yang ada di Polres Kediri sudah sesuai dengan ketentuan yang berlaku. Hal ini didukung dengan adanya uji kompetensi yang harus dilakukan oleh petugas pelayanan setiap enam bulan sekali guna untuk memenuhi standart pelayanan yang telah ditetapkan.

\section{Faktor-faktor yang Mempengaruhi Pelayanan Publik}

Pelayanan Publik merupakan sebuah bidang yang berhubungan langsung dengan masyarakat. Hal ini karena target pelayanannya terletak pada masyarakat. Di dalam melakukan pelayanan, petugas dituntut bekerja secara profesional sesuai dengan standart yang berlaku. Secara umum, akuntabilitas pelayanan publik dipengaruhi oleh dua faktor, yaitu faktor pendukung dan faktor penghambat.

Menurut Moenir (2015) terdapat beberapa faktor pendukung yang dapat mempengaruhi kinerja pelayanan publik, di antaranya adalah faktor kesadaran petugas yang sedang berkecimbung dalam pelayanan umum, faktor aturan yang menjadi sebuah landasan kerja pelayanan publik, faktor organisasi yang merupakan alat serta sistem yang memungkinkan berjalannya mekanisme kegiatan pada pelayanan, faktor pendapatan yang dapat memenui setiap kebutuhan hidup yang minimum, faktor keterampilan petugas dan faktor sarana dalam pelaksanaan tugas pada pelayanan.

Di samping itu, faktor-faktor yang menghambat proses dibagi menjadi dua macam, yaitu faktor internal dan faktor eksternal. Faktor internal yang dapat menghambat proses pelayanan yang pertama adalah rusaknya komputer yang dipakai dalam pengoperasian sistem secara online. Adanya kerusakan akan mengganggu kelancaran proses pelayanan dikarenakan petugas harus memperbaiki kerusakan tersebut agar pelayanan bisa diteruskan. Kedua, adanya trouble jaringan online. Saat jaringan tidak connect untuk akses internet, maka sistem online tidak dapat dijalankan. Gangguan jaringan ini bisa terjadi dikarena beberapa faktor baik dari server maupun faktor alam. Selain itu, faktor eksternal yang 
dapat menghambat proses pelayanan adalah kurang pahamnya pemohon terhadap adanya penerapan sistem online. Masalah kurangnya pemahaman masyarakat ini dikarenakan kurangnya sosialisasi dari SATPAS mengenai adanya penerapan sistem yang baru yaitu secara online.

Hasil dari penelitian ini menerangkan bahwa secara umum faktor yang menghambat proses pelayanan publik adalah masalah teknis. Masalah tersebut meliputi adanya ketidakstabilan pada server atau jaringan sehingga dapat membuat pelayanan tidak maksimal. Selain itu, kurang pahamnya masyarakat untuk prosedur pelayanan secara online juga menjadi salah satu penghambat yang perlu mendapat perhatian serius.

Hambatan-hambatan yang terjadi dalam proses pelayanan tentu sangat merugikan. Oleh karena itu, harus dilakukan upaya untuk mengatasinya. Pihak penyelenggara pelayanan sebelumnya dapat merekrut tenaga IT yang sangat berkompeten dalam bidang tersebut, sehingga ketika hambatan terjadi dapat menyelesaikannya dengan baik. Selain itu, pihak penyelenggara wajib mempunyai cadangan rencana jika sewaktu-waktu terjadi hambatan. Misalnya, menyiapkan pendaftaran secara manual, jika pendaftaran online sedang tidak bisa diakses.

\section{KESIMPULAN}

Berdasarkan hasil pembahasan peneliti pada bab sebelumnya mengenai Akuntabiltas Pelayanan penerbitan SIM di Polres Kediri, maka peneliti mengemukakan beberapa kesimpulan antara lain adalah akuntabilitas kinerja pelayanan publik pada Polres Kediri sudah baik. Dapat dilihat dari kesiapan petugas pelayanan dalam melayani permintaan masyarakat untuk membuat Surat Ijin Mengemudi (SIM), sarana dan prasarana yang memadai, dan tidak adanya penyimpanganpenyimpangan yang terjadi. Akuntabilitas biaya pelayanan publik yang dilakukan di Polres Kediri sudah baik. Hal ini dibuktikan dengan biaya pelayanan sudah sesuai dengan yang telah ditetapkan dalam perundang-undangan, tidak ada keluhan masyarakat mengenai biaya pelayanan SIM, dan antisipasi petugas untuk dapat meminimalisir adanya calo.

Akuntabilitas produk pelayanan publik pada Polres Kediri sudah baik. Hal ini dibuktikan dengan masalah persyaratan teknis dan administratif, keabsahan produk, serta pengambilan produk pelayanan di Polres Kediri yang sudah dapat dipertanggungjawabkan dan sudah sesuai dengan ketentuan yang berlaku. Faktor yang mendukung proses pelayanan publik di Polres Kediri adalah tanggungjawab petugas dan sarana prasarana yang tersedia. Sedangkan faktor penghambat proses pelayanan publik di Polres Kediri adalah masalah teknis yang meliputi adanya ketidakstabilan pada server.

Berdasarkan kesimpulan penelitian di atas maka penulis memberikan rekomendasi kepada Satpas Satlantas Polres Kediri bahwa Satpas Polres Kediri harus tetap mempertahankan pelayanan dengan kualitas yang lebih baik guna memberikan pelayanan yang maksimal kepada masyarakat. Hal ini tentunya menjadi patokan yang paling penting dalam pelayanan yang diberikan kepada masyarakat. Selain itu, untuk lebih meningkatkan pelayanan yang lebih baik lagi terkait diadakannya sosialisasi kepada masyarakat tentang proses pengajuan SIM secara online agar masyarakat lebih paham dengan proses tersebut.

Berkaitan dengan faktor yang mendukung proses pelayanan publik, diharapkan Polres Kediri bisa mempertahankan dan bahkan meningkatkan profesionalisme petugas yang ada pada bidang pelayanan publik. Selain itu sarana dan prasarana juga bisa lebih ditingkatkan lagi agar proses pelayanan menjadi lebih maksimal. Selain itu, berkaitan dengan faktor yang menghambat proses pelayanan publik, yaitu adanya masalah teknis, maka Polres Kediri membutuhkan seorang admin yang memiliki kemampuan yang cukup untuk menangani masalah server, sehingga proses pelayanan dapat dilakukan dengan baik.

\section{REFERENSI}

Faidati, N., \& Khozin, M. (2020). The Relevance of Administrative Accountability and Social Accountability and its Impact on Welfare Improvement: DIY Province Case Study. JIP (Jurnal Ilmu Pemerintahan): Kajian Ilmu Pemerintahan Dan Politik Daerah, 5(1), 12-19. https://doi.org/10.24905/jip.5.1.2020.12-19
Lavenia,
I. Y
(2018). Korupsi
Kolusi
Dan
Nepotisme.
INA-Rxiv. https://doi.org/10.31227/osf.io/zjqug 
Lestari, P. I., Nyoman Trisna Herawati, S. E. A., \& Dr. Anantawikrama Tungga Atmadja, S. E. (2018). Pengaruh Komitmen Organisasi, Pengawasan, Dan Ketepatan Waktu Terhadap Pengelolaan Anggaran Berkonsep Value For Money Pada Penyelenggara Pemerintahan Desa (Studi Empiris pada Pemerintah Desa di Kecamatan Seririt). JIMAT (Jurnal Ilmiah Mahasiswa Akuntansi) Undiksha, 8(2), Article 2. https://doi.org/10.23887/jimat.v8i2.14105

Media, K. C. (2018). Terlibat Kasus Pungli SIM, Kapolres Kediri Dimutasi. KOMPAS.com. https://regional.kompas.com/read/2018/09/13/23000081/terlibat-kasus-pungli-simkapolres-kediri-dimutasi

Moenir, H.A.S, (2015), Manajemen Pelayanan Umum di Indonesia, Jakarta, PT. Bhumi aksara

Moleong, L. (2014). Moleong metodologi penelitian kualitatif. http://booksnu.info/file/moleong-metodologi-penelitian-kualitatif-pdf

Munawaroh, S., Wulandari, W., Eldo, D. H. A. P., \& Aprilya, N. D. (2020). Reformasi Birokrasi Dalam Penerapan Prinsip Akuntabilitas Pada Pemerintah Kota Tegal Tahun 2018. TheJournalish: Social and Government, 1(2), 67-75.

Permatasari, I. A. (2020). Kebijakan Publik (Teori, Analisis, Implementasi Dan Evaluasi Kebijakan). TheJournalish: Social and Government, 1(1), 33-37.

Samudra, A. (2019). Tidak Lolos Ujian SIM, Biaya yang Disetor Bisa Ditarik Lagi? Ini Kata Polisi-GridOto.com. https://www.gridoto.com/read/221683709/tidak-lolos-ujiansim-biaya-yang-disetor-bisa-ditariklagi-ini-kata-polisi

Peraturan Menteri Negara Pendayagunaan Aparatur Negara No.24 Tahun 2006 Tentang Petunjuk Teknis Transparansi dan Akuntabilitas dalam penyelenggaraan Pelayanan Publik

Peraturan Pemerintah Republik Indonesia Nomor 50 Tahun 2010 Tentang Jenis Dan Tarif Atas Jenis Penerimaan Negara Bukan Pajak Yang Berlaku Pada Kepolisian Negara Republik Indonesia 